Bull. Fac. Agric., Cairo Univ., 67: 295- 306 (2016).

\title{
SELECTION FOR GRAIN YIELD UNDER NORMAL AND DEFICIT IRRIGATION REGIMES IN BREAD WHEAT
}

(Receied:8.11.2016)

\author{
By \\ A.G.Abd El-Rady \\ Wheat Research Department, Field Crops Research Institute, \\ Agriculture Research Center, Giza, Egypt.
}

\begin{abstract}
The objectives of the present research were to study the direct selection response for grain yield plant $^{-1}$ under normal and deficit irrigation conditions and estimate the correlated response of other studied traits. Two cycles of selection were practiced on a segregating populations of wheat cross (Sid $1 \times$ Misr 2) in the $F_{3}-F_{5}$ generations. Selection was practiced separately under normal and deficit irrigation conditions. The genotypic variance was slightly less than the phenotypic variance under both environments and generally decreased from the base population $\left(\mathrm{F}_{3}\right)$ to the $\mathrm{F}_{5}$ generation. Broad-sense heritability estimates for grain yield plant ${ }^{-1}$ after two cycles of selection were 65.66 and $59.95 \%$ under normal and deficit irrigation, respectively. The realized heritability under normal irrigation was 47.94 and $53.66 \%$ compared to 34.90 and $58.64 \%$ under deficit irrigation conditions after the first and second cycles of selection, respectively. The average observed gain for grain yield plant ${ }^{-1}$ from selection under normal and deficit irrigation groups, evaluated under normal irrigation were (13.92 and $15.48 \%)$ over the bulk sample and $(9.27$ and $10.78 \%)$ over the better parent, respectively. While, from selection under normal and deficit irrigation, evaluated under deficit irrigation were (16.87 and $20.08 \%)$ over the bulk sample and (15.44 and $18.61 \%)$ over the better parent, respectively. Drought susceptibility index (DSI) showed that six families selected under normal irrigation and five families selected under deficit irrigation were superior for drought tolerance and had high grain yield under deficit irrigation in $\mathrm{F}_{5}$ generation. The antagonistic selection was better than the synergistic selection in changing the mean and decreasing the sensitivity.
\end{abstract}

Key words: Selection response, Heritability, Drought susceptibility index, Synergistic vs antagonistic selection.

\section{INTRODUCTION}

Wheat is the most important food grain in the world and staple food for the people of Egypt. The cultivated area in Egypt reached 3.4 million feddans in 2014/2015 growing season, with an average yield of 18.00 ardab/feddan, and the total production was about 9.47 million tons (Economic Affairs Annual Report, 2015). In Egypt, wheat production is far below to meet the local consumption of the growing population of the country which resulted in increasing wheat imports. Increasing production per unit area appears to be the main possible alternative to reduce wheat production gap. Drought is an arising threat all over the world. Water stress is one of the main abiotic stresses and an important factor for reducing yield of cultivated plants in semi arid agricultural lands (Amin-Alim, 2011). Therefore, breeding programs should aim at developing high yielding cultivars over a wide range of stress and non-stress environments. The efficiency of a breeding program for drought tolerance depends largely on the selection criteria and the selection method used to achieve genetic improvement through selection, in addition to the complexity of drought tolerance itself (Passioura, 2007). Pedigree selection method can be used to identify superior genotypes for grain yield in a cultivar development program. Several workers indicated that pedigree selection is effective in improving grain yield (Kheiralla et al., 2001; Omara et al., 2004; Tammam et al., 2004, Ahmed, 2006 and El-Morshidy et al., 2010). On the other hand, breeding for drought tolerance should focus on increasing genetic variance and choosing a selection environment that is representative of the target environment. Some researchers 
believe in selection under favorable conditions (Betran et al., 2003), others prefer selection in a target stress condition (Rathjen, 1994), while others yet have chosen a mid-point and believe in selection under both favorable and stress conditions (Byrne et al., 1995). Pedigree selection for grain yield plant $^{-1}$ needs to evaluate selections under a series of environments such as different water stresses (Attia, 2003; Tammam et al., 2004 and El-Morshidy et al.,, 2010). Jinks and Connolly (1973 and 1975). Jinks and Pooni (1982) indicated that, environmental sensitivity was reduced if selection and environment effects were in opposite directions, while sensitivity was increased if selection and environment effects were in the same direction. The objectives of the present research were to estimate the direct and correlated responses for grain yield under normal and deficit irrigation, the relative merits of pedigree selection for grain yield plant ${ }^{-1}$ under normal and deficit irrigation, beside estimates drought susceptibility index and sensitivity to environmental conditions.

\section{MATERIALS AND METHODS}

The present research was carried out at Shandaweel Agric. Res. Station, Agricultural Research Center (ARC), Egypt, during $2013 / 2014$ to $2015 / 2016$ growing seasons. The breeding materials used were $100 \mathrm{~F}_{3}$ families traced back to 100 random $F_{2}$ plants originated from the cross (Sids $1 \times$ Misr 2 ). The pedigree and origin of the parents are presented in Table (1).

Table (1):The pedigree of the parents of the wheat population.

\begin{tabular}{|l|l|}
\hline Parent & \multicolumn{1}{|c|}{ pedigree } \\
\hline Sids 1 & $\begin{array}{l}\text { HD 2172 / PAVON"S" // 1158.57 / } \\
\text { MAYA 74"S" }\end{array}$ \\
\hline Misr 2 & SAKUZ / BAV 92 \\
\hline
\end{tabular}

In 2013/2014 growing season, $100 \quad \mathrm{~F}_{3}$ families, original parents and $F_{3}$ bulked random sample (a mixture of equal number of grains from each plant to represent the generation mean) were sown on $20^{\text {th }}$ of November in two field experiments using a randomized complete block design with three replications. The first experiment was grown in supplemental water applied regularly as recommended (normal) while the other one did not receive any irrigation after the second irrigation (deficit irrigation). Each plot consisted of a single row $3 \mathrm{~m}$ long, 30 $\mathrm{cm}$ apart and $10 \mathrm{~cm}$ between grains within row.
The recommended cultural practices for wheat production were adopted throughout the growing season in the two experiments. Data were recorded on ten guarded plants from each family for days to heading, days to maturity, number of spikes plant ${ }^{-1}$, number of kernels spike ${ }^{-1}, 100$ kernel weight, grain yield plant ${ }^{-1}$ and biological yield plant ${ }^{-1}$. Separate analysis of variance of the two treatments was applied on a plot mean basis. The best high yielding 20 plants from the best high yielding 20 families were saved to give the $\mathrm{F}_{4}$ families in each environment.

In 2014/2015 growing season, the $20 \mathrm{~F}_{4}$ families selected under normal irrigation with parents and $\mathrm{F}_{4}$ bulk sample were sown under normal irrigation and the $20 \mathrm{~F}_{4}$ families selected under deficit irrigation with parents and $\mathrm{F}_{4}$ bulk sample were sown under water stress. The experimental design, number of replications, planting date and cultural practices were properly adopted as the same in the first season. Data were recorded as previously mentioned. Each group of families (20 families) for each environment of selection was analyzed separately. The best 10 high yielding plants from the best high yielding 10 families were saved in each environment to give the $\mathrm{F}_{5}$ families.

In 2015/2016 growing season, the $10 \mathrm{~F}_{5}$ families for each environment of selection, the parents and $\mathrm{F}_{5}$ bulk sample were evaluated under the two environments in two separate experiments. Again, experimental design, number of replications, field procedures and recorded data were the same as in the first and second seasons.

\section{Statistical analysis}

Analysis of variance was performed according to Snedecor and Cochran (1980). Genotype means were compared using Revised Least Significant Differences (RLSD) test at 5 and $1 \%$ level of probability, according to ElRawi and Khalafala (1980). The phenotypic $\left(\sigma^{2} p\right)$ and genotypic $\left(\sigma^{2} g\right)$ variances and heritability in the broad sense $\left(\mathrm{h}^{2}\right.$ bs $)$ were calculated according to Walker (1960). The phenotypic (PCV\%) and genotypic (GCV\%) coefficients of variability were calculated as outlined by Burton (1952), Realized heritability $\mathrm{h}^{2}=\mathrm{R} / \mathrm{S}$ was calculated according to Falconer (1989); where R (response to selection) =cycle mean - bulk mean and S (selection differential) $=$ mean of selections - bulk mean. Drought susceptibility index (DSI) was computed according to the method of Fischer and Maurer (1978) equation: 
DSI $=\left(1-Y_{d} / Y_{p}\right) / D$

Where:

$\mathrm{Y}_{\mathrm{d}}=$ Mean yield in stress environment $\mathrm{Y}_{\mathrm{p}}=$ Mean yield in non stress environment

$\mathrm{D}=1$ - (mean $\mathrm{Y}_{\mathrm{d}}$ of all genotypes/mean $\mathrm{Y}_{\mathrm{p}}$ of all genotypes).The sensitivity and relative merits of selected families were assessed as described by Falconer (1990): The sensitivity of any selected line is the difference between its performance in the high and low environments divided by the same difference in the base population or in a contemporaneous unselected control. The relative merits of the two types of selection in changing the mean is expressed as the ratio:

(Change of mean by antagonistic selection) / (Change of mean by Synergistic selection)

Synergistic selection: Selection upwards in a good environment or downwards in a bad,environment selection and environment acting in the same direction on the character.

Antagonistic selection: Selection upwards in a bad environment or downwards in a good environment, selection and environment acting in opposite direction on the character.

\subsection{Base population \\ 3.RESULTS AND DISCUSSION}

The analysis of variance (Table 2) indicated highly significant differences among the $F_{3}$ families for all the studied traits under normal and deficit irrigation. This indicates that the genetic variability existed among selected families in these traits and selection in the base population would be effective. The averages of the studied traits were 93.18 and 90.27 day for days to heading, 146.98 and 140.68 day for days to maturity, 11.69 and 10.13 for the number of spikes plant ${ }^{-1}, 37.46$ and 35.71 for the number of kernels spike ${ }^{-1}, 4.42$ and 3.39 for 100-kernel weight, 52.92 and $44.42 \mathrm{~g}$ for biological yield plant $^{-1}$ and 20.03 and $15.98 \mathrm{~g}$ for grain yield plant $^{-1}$ under normal and deficit irrigation, respectively. These results indicated that deficit irrigation caused reduction in all the studied traits. Similar results were reported by Kheiralla et al. (2004), Mahdy (2007) and Soliman, et al. (2015), who reported that deficit irrigation caused a reduction in the number of spikes plant ${ }^{-}$ ${ }^{1}$, number of kernels spike ${ }^{-1}, 100$-kernel weight, biological yield plant ${ }^{-1}$ and grain yield plant ${ }^{-1}$

The phenotypic (PCV) and genotypic (GCV) coefficient of variability were 5.34 and $4.95 \%$ for days to heading, 3.30 and $3.05 \%$ for days to maturity, 12.02 and $9.73 \%$ for the number of spikes plant ${ }^{-1}, 11.43$ and $10.11 \%$ for the number of kernels spike ${ }^{-1}, 7.91$ and $6.87 \%$ for 100 -kernel weight, 16.51 and $15.15 \%$ for biological yield plant ${ }^{-1}$ and 19.78 and $18.00 \%$ for grain yield plant $^{-1}$, respectively under normal irrigation, while under deficit irrigation they were 5.96 and $5.45 \%, 3.19$ and $2.90 \%, 13.42$ and $10.14 \%, 11.40$ and $10.04 \%, 10.22$ and $8.85 \%$, 16.76 and $14.87 \%$ and 22.13 and $19.53 \%$, respectively for the above mentioned traits, respectively. These results indicated the presence of sufficient variability for grain yield among the families in the base population, which are characteristics of the starting population and have a considerable effect on early generation selection. In addition, great response to selection can be achieved from selection in such population having a large amount of phenotypic and genotypic variance. These findings are in line with those reported by Ismail (1995), Amin (2003), Zakaria et al. (2008), El-Morshidy et al. (2010), Ali (2011), Abd-El-Haleem et al. (2012), Ahmed et al. (2014) and Soliman et al. (2015) who found satisfactory genotypic coefficient of variation in grain yield in the $\mathrm{F}_{3}$ families.

Heritability estimate is considered one of the most important parameters for selection response in early generations. The current results showed that the broad sense heritability (Table 2) was 86.12 and $83.54 \%$ for days to heading, 85.08 and $82.27 \%$ for days to maturity, 65.54 and $64.86 \%$ for the number of spikes plant ${ }^{-1}$, 78.29 and $77.61 \%$ for the number of kernels spike $^{-1}, 75.48$ and $75.00 \%$ for 100 -kernel weight, 84.22 and $78.67 \%$ for biological yield plant ${ }^{-1}$ and 82.74 and $77.93 \%$ for grain yield plant ${ }^{-1}$ under normal and deficit irrigation, respectively. These results indicated that the environmental effects were small as compared to the genetic effects and were higher under normal irrigation than under deficit irrigation. This could mainly be due to the higher estimates of the phenotypic variance of the $F_{3}$ population under deficit irrigation than under normal irrigation. Kashif and Khaliq (2004), Cheema et al. (2006) and Zakaria et al. (2008) reported high broad-sense heritability for grain yield plant ${ }^{-1}$. Soliman et al. (2015) recorded that heritability estimate for grain yield under non-stress conditions was slightly higher than that under stress conditions.

\subsection{Selection for grain yield plant ${ }^{-1}$}

\subsubsection{Variability and heritability estimates}

After two cycles of selection for grain yield plant $^{-1}$, there were highly significant differences among selected families for the selection criterion; grain yield and other traits either 
Table (2): Mean performance, ranges, mean squares (MS), phenotypic (PCV\%) and genotypic (GCV\%) coefficients of variability and heritability in broad sense $\left(h^{2}{ }_{b s}\right)$ for seven studied traits under normal and deficit irrigation in the base population $\left(\mathrm{F}_{3}\right.$ generation).

\begin{tabular}{|c|c|c|c|c|c|c|c|c|}
\hline \multirow{2}{*}{ 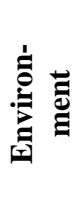 } & \multirow[b]{2}{*}{ Item } & $\begin{array}{l}\text { Selection } \\
\text { criterion }\end{array}$ & \multicolumn{6}{|c|}{ Correlated traits to selection } \\
\hline & & $\begin{array}{l}\text { Grain yield } \\
\text { plant }^{-1}\end{array}$ & $\begin{array}{l}\text { Days to } \\
\text { heading }\end{array}$ & $\begin{array}{l}\text { Days to } \\
\text { maturity }\end{array}$ & $\begin{array}{l}\text { No. of } \\
\text { spikes } \\
\text { plant }^{-1}\end{array}$ & $\begin{array}{l}\text { No. of kernels } \\
\text { spike }^{-1}\end{array}$ & $\begin{array}{c}\text { 100- } \\
\text { kernel } \\
\text { weight }\end{array}$ & $\begin{array}{l}\text { Biological } \\
\text { yield }\end{array}$ \\
\hline \multirow{11}{*}{ 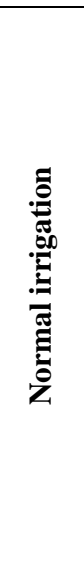 } & Sids 1 & 18.75 & 94.67 & 148.33 & 12.02 & 38.04 & 4.11 & 50.91 \\
\hline & Misr 2 & 21.00 & 92.67 & 144.67 & 12.21 & 38.74 & 4.45 & 53.64 \\
\hline & $F_{3}$ families & $20.03 \pm 0.95$ & $93.18 \pm 1.06$ & $146.98 \pm 1.08$ & $11.69 \pm 0.48$ & $37.46 \pm 1.15$ & $4.42 \pm 0.10$ & $52.92 \pm 2.00$ \\
\hline & Bulk & 17.92 & 94.67 & 149.33 & 12.23 & 39.35 & 3.74 & 45.98 \\
\hline & Range & $11.71-29.38$ & $74.00-106.00$ & $132.00-156.67$ & $9.21-14.54$ & $28.20-52.22$ & $3.55-5.47$ & $32.7-74.4$ \\
\hline & Rep. MS & 6.76 & 1.40 & 2.02 & 0.02 & 23.24 & 0.01 & 22.76 \\
\hline & Families MS & $41.69 * *$ & $67.29 * *$ & $63.58^{* *}$ & $4.55 * *$ & $47.05^{* *}$ & $0.30 * *$ & $204.98 * *$ \\
\hline & Error MS & 2.71 & 3.42 & 3.52 & 0.68 & 3.98 & 0.03 & 12.05 \\
\hline & (PCV\%) & 19.78 & 5.34 & 3.30 & 12.02 & 11.43 & 7.91 & 16.51 \\
\hline & (GCV\%) & 18.00 & 4.95 & 3.05 & 9.73 & 10.11 & 6.87 & 15.15 \\
\hline & $\mathbf{h}_{\mathrm{bs}}^{2}$ & 82.74 & 86.12 & 85.08 & 65.54 & 78.29 & 75.48 & 84.22 \\
\hline \multirow{11}{*}{ 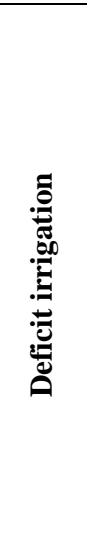 } & Sids 1 & 15.78 & 89.67 & 143.67 & 11.44 & 37.99 & 3.64 & 42.33 \\
\hline & Misr 2 & 15.50 & 87.33 & 140.67 & 11.13 & 36.99 & 3.79 & 40.33 \\
\hline & $F_{3}$ families & $15.98 \pm 0.96$ & $90.27 \pm 1.26$ & $140.68 \pm 1.05$ & $10.13 \pm 0.47$ & $35.71 \pm 1.11$ & $3.39 \pm 0.1$ & $44.42 \pm 1.98$ \\
\hline & Bulk & 14.00 & 91.33 & 144.33 & 11.08 & 37.8 & 3.37 & 42.00 \\
\hline & Range & $7.25-24.79$ & $72.00-100.67$ & $127.67-155.33$ & $7.25-13.00$ & $25.31-49.04$ & $2.58-4.00$ & $29.67-59.67$ \\
\hline & Rep. MS & 11.81 & 4.12 & 1.69 & 0.36 & 20.46 & 0.01 & 60.08 \\
\hline & Families MS & $31.99 * *$ & $77.41^{* *}$ & $53.42 * *$ & $4.25 * *$ & $42.28^{* *}$ & $0.30 * *$ & $142.62 * *$ \\
\hline & Error MS & 2.76 & 4.77 & 3.35 & 0.65 & 3.71 & 0.03 & 11.82 \\
\hline & (PCV\%) & 22.13 & 5.96 & 3.19 & 13.42 & 11.40 & 10.22 & 16.76 \\
\hline & (GCV\%) & 19.53 & 5.45 & 2.90 & 10.14 & 10.04 & 8.85 & 14.87 \\
\hline & $\mathbf{h}^{2}{ }_{\mathrm{bs}}$ & 77.93 & 83.54 & 82.27 & 64.86 & 77.61 & 75.00 & 78.67 \\
\hline
\end{tabular}

**significant at $1 \%$ levels of probability.

selection was practiced under normal or deficit irrigation (Table 3). This reflects the existence of sufficient variability for further improvement. These results agreed with those reported by Zarei et al. (2007), El-Morshidy et al. (2010), Nazari and Pakniyat (2010), Mahdy, (2012) and Soliman et al. (2015).

The effect of selection for two cycles on variability and heritability estimates of grain yield plant $^{-1}$ is shown in Table (4). The phenotypic variance in grain yield plant $^{-1}$ was high in the $\mathrm{F}_{3}$ generation under both normal and deficit irrigation and dropped rapidly after cycle 1 and 2. The phenotypic variance under normal irrigation was 15.70, 9.00 and 6.38 in the base population, after $\mathrm{C}_{1}$ and $\mathrm{C}_{2}$, respectively. Under deficit irrigation, the phenotype variance was 12.50 in the base population and decreased to
4.39 and 2.80 in $\mathrm{C}_{1}$ and $\mathrm{C}_{2}$, respectively. This may be due to the increase of homozygosity in the $F_{5}$ generation, which could result in separate different lines. The genotypic variance goes in line with the phenotypic variance. The phenotypic and genotypic coefficient of variability under normal irrigation were (19.78 and $18 \%),(13.89$ and $12.11 \%)$ and (10.49 and $8.50 \%)$ for base population, $\mathrm{F}_{4}\left(\mathrm{C}_{1}\right)$ and $\mathrm{F}_{5}\left(\mathrm{C}_{2}\right)$, respectively. While, they were $(22.13$ and19.53\%), (12.72 and 10.81\%) and(7.94 and $6.15 \%)$ under deficit irrigation for base population, $\mathrm{F}_{4}\left(\mathrm{C}_{1}\right)$ and $\mathrm{F}_{5}\left(\mathrm{C}_{2}\right)$,respectively. It appears that $\mathrm{PCV} \%$ and $\mathrm{GCV} \%$ were decreased after two cycles of selection for grain yield plant ${ }^{-1}$, but still sufficient for further cycles of selection. The GCV\% was slightly less than the PCV\% under both environments. 
Table( 3): Mean squares for families selected for high grain yield plant ${ }^{-1}$ and correlated traits

\begin{tabular}{|c|c|c|c|c|c|c|c|c|c|c|}
\hline \multirow{2}{*}{ 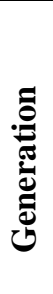 } & \multirow{2}{*}{ 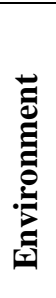 } & \multirow{2}{*}{ S. O. V. } & \multirow{2}{*}{$\mathbf{d} \mathbf{f}$} & \multirow{2}{*}{$\begin{array}{c}\text { Selecti } \\
\text { on } \\
\text { criteri }\end{array}$} & \multicolumn{6}{|c|}{ Correlated traits } \\
\hline & & & & & $\begin{array}{l}\text { Days to } \\
\text { heading }\end{array}$ & $\begin{array}{l}\text { Days to } \\
\text { maturity }\end{array}$ & $\begin{array}{l}\text { No. of } \\
\text { spikes } \\
\text { plant }^{-1}\end{array}$ & $\begin{array}{l}\text { No. of } \\
\text { kernels } \\
\text { spike }^{-1}\end{array}$ & $\begin{array}{c}100- \\
\text { kernel } \\
\text { weight }\end{array}$ & $\begin{array}{c}\text { Biologi } \\
\text { cal } \\
\text { yield }\end{array}$ \\
\hline \multirow{6}{*}{$\mathbf{F}_{4}$} & \multirow{3}{*}{$\mathbf{N}$} & Rep. & 2 & 0.42 & 0.62 & 19.11 & 0.42 & 3.57 & 0.05 & 17.11 \\
\hline & & Fam. & 19 & $22.69 *$ & $65.31 * *$ & $48.28 * *$ & $4.47 * *$ & $29.16^{* *}$ & $0.18 * *$ & $157.87 * *$ \\
\hline & & Error & 38 & 2.15 & 3.65 & 3.76 & 0.73 & 3.45 & 0.02 & 16.53 \\
\hline & \multirow{3}{*}{ D } & Rep. & 2 & 2.83 & 2.51 & 26.31 & 0.08 & 1.22 & 0.19 & 1.86 \\
\hline & & Fam. & 19 & $10.74 *$ & $79.85 * *$ & $52.89 * *$ & $3.28 * *$ & $26.53 * *$ & $0.29 * *$ & $72.86^{* * *}$ \\
\hline & & Error & 38 & 1.22 & 6.62 & 4.93 & 0.61 & 3.16 & 0.03 & 11.63 \\
\hline \multirow{6}{*}{$\mathbf{F}_{5}$} & \multirow{3}{*}{$\mathbf{N}$} & Rep. & 2 & 1.28 & 1.85 & 4.11 & 0.27 & 0.32 & 0.03 & 16.16 \\
\hline & & Fam. & 19 & $14.75^{*}$ & $32.15^{* *}$ & $23.11^{* *}$ & $2.79 * *$ & $17.63^{* *}$ & $0.22 * *$ & $283.55^{* * *}$ \\
\hline & & Error & 38 & 2.19 & 2.13 & 1.90 & 0.56 & 2.81 & 0.31 & 33.87 \\
\hline & \multirow{3}{*}{ D } & Rep. & 2 & 1.18 & 3.26 & 4.01 & 0.42 & 1.14 & 0.05 & 8.45 \\
\hline & & Fam. & 19 & $6.14 * *$ & $31.26^{* *}$ & $33.70^{* *}$ & $2.41 * *$ & $10.93^{* *}$ & $0.21 * *$ & $154.55^{* * *}$ \\
\hline & & Error & 38 & 1.25 & 3.58 & 5.01 & 0.52 & 1.84 & 0.03 & 22.05 \\
\hline
\end{tabular}

$\mathrm{N}=$ normal irrigation $\quad \mathrm{D}=$ deficit irrigation $\quad * *$ Significant at $1 \%$ level of probability.

Table (4): Variability and heritability estimates of grain yield plant $^{-1}$ after two cycles of selection under normal $(\mathrm{N})$ and deficit irrigation (D) regimes.

\begin{tabular}{|c|c|c|c|c|c|c|c|c|c|c|c|c|}
\hline \multirow{2}{*}{$\begin{array}{c}\text { Selection } \\
\text { cycle }\end{array}$} & \multicolumn{2}{|c|}{$\sigma_{p}^{2}$} & \multicolumn{2}{|c|}{$\sigma^{2} g$} & \multicolumn{2}{|c|}{ PCV \% } & \multicolumn{2}{|c|}{ GCV \% } & \multicolumn{2}{|c|}{$\mathbf{h}^{2}{ }_{\text {bs }} \%$} & \multicolumn{2}{|c|}{$\begin{array}{c}\text { Realized } \\
\text { heritability }\end{array}$} \\
\hline & $\mathbf{N}$ & D & $\mathbf{N}$ & D & $\mathbf{N}$ & D & $\mathbf{N}$ & D & $\mathbf{N}$ & D & $\mathbf{N}$ & D \\
\hline $\begin{array}{c}\text { Base } \\
\text { populati } \\
\text { on }\left(F_{3}\right)\end{array}$ & 15.70 & 12.50 & 12.99 & 9.74 & 19.78 & 22.13 & 18.00 & 19.53 & 82.74 & 77.93 & --- & --- \\
\hline $\begin{array}{c}\mathbf{F}_{4} \\
\text { families } \\
\left(\mathbf{C}_{1}\right)\end{array}$ & 9.00 & 4.39 & 6.85 & 3.17 & 13.89 & 12.72 & 12.11 & 10.81 & 76.10 & 72.23 & 47.94 & 34.90 \\
\hline $\begin{array}{c}\mathbf{F}_{5} \\
\text { families } \\
\left(\mathbf{C}_{2}\right)\end{array}$ & 6.38 & 2.80 & 4.19 & 1.68 & 10.49 & 7.94 & 8.50 & 6.15 & 65.66 & 59.95 & 53.66 & 58.64 \\
\hline
\end{tabular}

$\mathrm{N}=$ normal irrigation

$\mathrm{D}=$ deficit irrigation

Heritability in a broad sense for grain yield plant $^{-1}$ under normal and deficit irrigation were (82.74 and $77.93 \%),(76.10$ and $72.23 \%)$ and (65.66 and $59.95 \%)$ for base population, $\mathrm{F}_{4}$ selected families $\left(\mathrm{C}_{1}\right)$ and $\mathrm{F}_{5}$ selected families $\left(\mathrm{C}_{2}\right)$, respectively. It is of interest to note that heritability estimates for grain yield plant $^{-1}$ decreased from the $\mathrm{F}_{3}$ to the $\mathrm{F}_{5}$ generation. This could be due to the increase in experimental error; in other words the environmental variance as the homozygozity of the lines increased, which maximized the phenotypic relative to the genotypic variance. Also the realized heritability increased from $\mathrm{C}_{1}$ (47.94 and $\left.34.90 \%\right)$ to $\mathrm{C}_{2}$ (53.66 and 58.64\%) under normal and deficit irrigation, respectively. These results are in agreement with those reported by Zakaria (2004), Ahmed (2006), Abd El-Kader (2011), 
Ali (2011), Mahdy et al. (2012) and Soliman et al. (2015).

\subsubsection{Means and observed gains under} normal irrigation evaluation

The group of $F_{5}$ families selected for high grain yield plant ${ }^{-1}$ under normal irrigation and evaluated under normal irrigation (Table 5), ranged from 21.32 to $26.80 \mathrm{~g}$ with an average of
$23.92 \mathrm{~g} \mathrm{plant}^{-1}$ (Table 5). The average observed gain was 13.92 and $9.27 \% \mathrm{~g} \mathrm{plant}^{-1}$ from the bulk and better parent, respectively. The selected families of No. 17, 27, 37, 67 and 74 showed significant observed gain over the bulk sample, four of them significantly surpassed the better parent. The group of $F_{5}$ families selected under deficit irrigation and evaluated under normal

Table (5): Mean grain yield plant ${ }^{-1}$ and observed gain over the bulk sample (OG\% Bulk) and over the better parent (OG\% BP) for the high grain yield plant ${ }^{-1}$ selected families after two cycles of selection under normal and deficit irrigation regimes.

\begin{tabular}{|c|c|c|c|c|c|c|c|c|}
\hline \multirow{3}{*}{\multicolumn{2}{|c|}{ Item }} & \multirow{4}{*}{$\begin{array}{c}\text { Fam. No. } \\
7\end{array}$} & \multicolumn{6}{|c|}{ Environment of evaluation } \\
\hline & & & \multicolumn{3}{|c|}{ Normal irrigation } & \multicolumn{3}{|c|}{ Deficit irrigation } \\
\hline & & & Mean & OG\% Bulk & OG\% BP & Mean & OG\% Bulk & OG\% BP \\
\hline \multirow{22}{*}{ 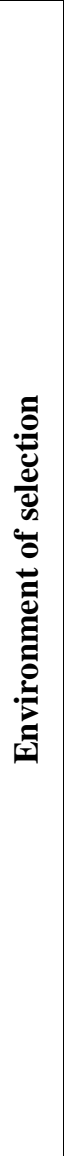 } & \multirow{11}{*}{ 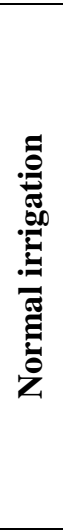 } & & 23.39 & 11.36 & 6.83 & 21.52 & $21.05^{* *}$ & $19.57^{* *}$ \\
\hline & & 17 & 26.13 & $14.43^{* *}$ & $19.37 * *$ & 21.17 & $19.09^{* *}$ & $17.63 * *$ \\
\hline & & 23 & 21.32 & 1.52 & -2.60 & 18.65 & 4.87 & 3.59 \\
\hline & & 27 & 25.51 & $21.46^{* *}$ & $16.52 * *$ & 21.00 & $18.14 * *$ & $16.69^{* *}$ \\
\hline & & 37 & 26.45 & $25.93 * *$ & $20.81 * *$ & 20.66 & $16.19^{* * *}$ & $14.77 * *$ \\
\hline & & 47 & 22.45 & 6.90 & 2.55 & 21.37 & $20.18^{* *}$ & $18.72 * *$ \\
\hline & & 57 & 22.24 & 5.89 & 1.58 & 17.92 & 0.79 & -0.44 \\
\hline & & 67 & 26.80 & $27.92 * *$ & $22.72 * *$ & 23.67 & $32.58^{* * *}$ & $30.96 * *$ \\
\hline & & 74 & 23.51 & $11.94 *$ & 7.39 & 21.72 & $22.14 * *$ & $20.65 * *$ \\
\hline & & 91 & 21.34 & 1.60 & -2.53 & 20.23 & $13.77 * *$ & $12.38 * *$ \\
\hline & & Average & 23.92 & $13.92 *$ & 9.27 & 20.78 & $16.87^{* * *}$ & $15.44 * *$ \\
\hline & \multirow{11}{*}{ 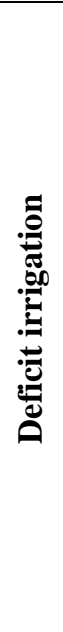 } & 8 & 23.69 & $12.79 *$ & 8.21 & 21.41 & $20.41^{* *}$ & $18.94 * *$ \\
\hline & & 9 & 25.56 & $21.71 * *$ & $16.76^{* *}$ & 23.70 & $33.28^{* * *}$ & $31.65 * *$ \\
\hline & & 11 & 25.44 & $21.13 * *$ & $16.20 * *$ & 20.80 & $17.00^{* * *}$ & $15.57 * *$ \\
\hline & & 13 & 28.67 & $36.54 * *$ & $30.99 * *$ & 22.66 & $27.47 * *$ & $25.91 * *$ \\
\hline & & 16 & 21.55 & 2.62 & -1.55 & 20.71 & $16.46^{* *}$ & $15.04 * *$ \\
\hline & & 32 & 24.18 & $15.14 *$ & 10.46 & 20.81 & $17.05^{* *}$ & $15.62 * *$ \\
\hline & & 41 & 22.63 & 7.77 & 3.39 & 21.67 & $21.87^{* * *}$ & $20.38 * *$ \\
\hline & & 50 & 26.94 & $28.29 * *$ & $23.07 * *$ & 22.23 & $25.00 * *$ & $23.48 * *$ \\
\hline & & 59 & 21.35 & 1.66 & -2.48 & 20.23 & $13.77^{* *}$ & $12.38 * *$ \\
\hline & & 64 & 22.51 & 7.20 & 2.84 & 19.34 & $8.75^{*}$ & 7.42 \\
\hline & & Average & 24.25 & $15.48^{*}$ & 10.78 & 21.35 & $20.08^{* * *}$ & $18.61 * *$ \\
\hline \multicolumn{3}{|c|}{ R.L.S.D. ${ }_{0.05}$} & 2.48 & ------ & ----- & 1.64 & ----- & ----- \\
\hline \multicolumn{3}{|c|}{ R.L.S.D. 0.01} & 3.29 & ----- & ------ & 2.16 & ------ & ------ \\
\hline \multicolumn{3}{|c|}{ Sids1 } & 19.98 & ----- & ------ & 18.00 & ------ & ----- \\
\hline \multicolumn{3}{|c|}{ Misr 2} & 21.89 & ----- & ----- & 17.80 & ----- & ----- \\
\hline \multicolumn{3}{|c|}{ Bulk } & 21.00 & ----- & ----- & 17.78 & ----- & ---- \\
\hline \multicolumn{3}{|c|}{$\mathrm{OG}=$ observed gain } & & $*, * *$ Significa & it 5 and $1 \%$ & els of pr & ility, respecti & \\
\hline
\end{tabular}


irrigation, ranged from 21.35 to $28.67 \mathrm{~g}$ with an average of $24.25 \mathrm{~g} \mathrm{plant}^{-1}$. The average observed gain significantly out yielded the bulk sample by $15.48 \%$ and the better parent by $10.78 \%$. Six out of these families (No. 8, 9, 11, 13, 32 and 50) showed significant and highly significant observed gain over the bulk sample, four of them i.e., No. 9, 11, 13 and 50, showed highly significant observed gain over the better parent.

\subsubsection{Correlated response to selection}

Estimates of direct and correlated gain for grain yield plant ${ }^{-1}$ under normal and deficit irrigation after the first and second cycles are shown in Table (6). Direct selection for high grain yield plant ${ }^{-1}$ for two selection cycles under normal irrigation and evaluated under normal irrigation increased the number of spikes plant ${ }^{-1}$ $(9.17 \%)$, number of kernels spike ${ }^{-1}(8.23 \%)$ and biological the yield plant $^{-1}(36.52 \%)$, while it decreased days to heading $(-4.93 \%)$, days to maturity $(-3.08 \%)$ and 100-kernel weight $(-2.32)$ than the bulk sample. Also, this direct selection increased days to heading (1.53\%), the number of spikes plant ${ }^{-1}(3.27 \%)$, number of kernels spike $^{-1},(4.22 \%), 100$-kernel weight (1.76) and biological yield plant $^{-1}(27.64 \%)$, while it decreased days to maturity $(-0.59 \%)$ than the better parent. Direct selection for high grain yield plant $^{-1}$ for two cycles under deficit irrigation and evaluated under normal irrigation increased the number of spikes plant ${ }^{-1}(14.10 \%)$, the number of kernels spike ${ }^{-1}(10.51 \%)$ and biological yield plant $^{-1}(20.73 \%)$ and decreased days to heading $(-2.15 \%)$, days to maturity $(-1.44 \%)$ and 100 -kernel weight (-8.02) than the bulk sample, while it increased days to heading (4.50\%), days to maturity $1.09 \%$ ) the number of spikes plant ${ }^{-1}(7.94 \%)$, number of kernels spike ${ }^{-1}$, (6.41\%), and biological yield plant ${ }^{-1}(12.87 \%)$ and decreased100-kernel weight $(-4.18 \%)$ than the better parent.

\subsubsection{Means and observed gains under deficit irrigation evaluation}

The group of $F_{5}$ families selected under normal irrigation and evaluated under deficit irrigation (Table 5), ranged in grain yield plant ${ }^{-1}$ from 17.92 to 23.67 with an average of $20.78 \mathrm{~g}$ plant $^{-1}$. The observed gain significantly $(P<0.01)$ out-yielded the bulk sample and better parent by 16.87 and $15.44 \%$, respectively, and it varied from $0.79 \%$ for family No. 57 to $32.58 \%$ for family No. 67 and from $-0.44 \%$ for family No. 57 to $30.96 \%$ for family No. 67 compared to the bulk sample and better parent, respectively. All selected families, except family No. 23 and No.
57 significantly $(P<0.01)$ out-yielded the bulk sample and better parent. On the other hand, grain yield of the group of $\mathrm{F}_{5}$ families selected under deficit irrigation and evaluated under deficit irrigation, ranged from 19.34 to $23.70 \mathrm{~g}$ with an average of $21.35 \mathrm{~g}$ plant $^{-1}$. The observed gain significantly $(P<0.01)$ out-yielded the bulk sample and better parent by 20.08 and $18.61 \%$, respectively and it varied from $8.75 \%$ for family No. 64 to $33.28 \%$ for family No. 9, and from $7.42 \%$ for family No. 64 to $31.65 \%$ for family No. 9 , as compared to the bulk sample and better parent, respectively. All selected families showed significant $(P<0.01)$ observed gain over the bulk sample, while all selected families except family No. 64 showed highly significant observed gain over the better parent.

\subsubsection{Correlated response to selection}

Selection for high grain yield plant ${ }^{-1}$ for two cycles under normal irrigation and evaluated under deficit irrigation (Table 6) increased the number of spikes plant ${ }^{-1}(6.30 \%)$, the number of kernels spike $^{-1},(11.06 \%)$ and biological yield plant $^{-1}(35.98 \%)$ and decreased days to heading $(-4.46 \%)$, days to maturity $(-4.01 \%)$ and 100 kernel weight $(-0.66 \%)$ than the bulk sample, while it increased the number of spikes plant ${ }^{-1}$ $(8.45 \%)$, the number of kernels spike ${ }^{-1}(3.29 \%)$, 100 -kernel weight $(0.45 \%)$ and biological yield plant $^{-1}(28.42 \%)$ and decreased days to heading $(-1.37 \%)$ and days to maturity $(-1.73 \%)$ than the better parent. On the other hand, selection for high grain yield plant $^{-1}$ for two cycles under deficit irrigation and evaluated under deficit irrigation increased number of spikes plant ${ }^{-1}$ (11.52 and $13.77 \%$ ), number of kernels spike ${ }^{-1}$ (14.00 and 6.02\%) and biological yield plant ${ }^{-1}$ (22.99 and 16.15\%) and decreased days to heading (-4.15 and $-1.05 \%)$ and days to maturity $(-2.97$ and $-0.67 \%)$ and 100 -kernel weight $(-5.30$ and $-4.24 \%$ ) than the bulk sample and better parent, respectively.

These results indicated that the pedigree method of selection was effective in isolating high yield genotypes and the direct selection for grain yield per se was effective. Also, the current results stated that selection for high grain yield plant ${ }^{-1}$ for the two cycles under deficit irrigation was better than selection under normal irrigation either evaluation was practiced under normal or under deficit irrigation. These results are in line with those reported by Attia (2003), Zakaria (2004), Ahmed (2006), Abd El-Kader (2011), Mahdy et al. (2012), Mahdy (2012) and Soliman et al. (2015). Ali (2011) indicated that 
Table (6): Direct and correlated gain for grain yield plant $^{-1}$ in the two cycles of selection in percentages over the bulk OG \% (Bulk) and the better parent OG\% (BP) under normal irrigation (N) and deficit irrigation (D) regimes.

\begin{tabular}{|c|c|c|c|c|c|c|c|c|}
\hline \multirow{2}{*}{\multicolumn{2}{|c|}{ Item }} & $\begin{array}{l}\text { Grain } \\
\text { yield } \\
\text { plant }^{-1}\end{array}$ & $\begin{array}{l}\text { Days to } \\
\text { heading }\end{array}$ & $\begin{array}{c}\text { Days to } \\
\text { maturity }\end{array}$ & $\begin{array}{l}\text { No. spikes } \\
\text { plant }^{-1}\end{array}$ & $\begin{array}{c}\text { No. } \\
\text { kernels } \\
\text { spike }^{-1}\end{array}$ & $\begin{array}{c}\text { 100-kernel } \\
\text { weight }\end{array}$ & $\begin{array}{c}\text { Biological } \\
\text { yield }\end{array}$ \\
\hline & & \multicolumn{7}{|c|}{ Evaluation under normal irrigation } \\
\hline \multicolumn{2}{|c|}{$F_{4}$ families $\left(C_{1}\right)$} & 21.60 & 89.53 & 141.43 & 12.60 & 38.21 & 4.50 & 62.18 \\
\hline \multicolumn{2}{|c|}{ Bulk sample } & 17.98 & 93.33 & 147.33 & 12.14 & 34.08 & 4.38 & 48.67 \\
\hline \multicolumn{2}{|l|}{ Sids 1 (P1) } & 19.83 & 92.00 & 144.33 & 11.92 & 38.72 & 4.30 & 55.00 \\
\hline \multicolumn{2}{|l|}{ Misr 2 (P2) } & 20.97 & 88.33 & 140.67 & 12.53 & 39.41 & 4.34 & 53.33 \\
\hline \multicolumn{2}{|l|}{ OG\% (Bulk) } & $20.13^{*}$ & $-4.07 *$ & $-4.00 * *$ & 3.79 & $12.12^{*}$ & 2.74 & $27.76^{* *}$ \\
\hline \multicolumn{2}{|l|}{ OG\% (BP) } & 3.0 & 1.36 & 0.54 & 0.56 & -3.04 & 3.69 & $13.05^{*}$ \\
\hline \multirow{2}{*}{$F_{5}$ families $\left(C_{2}\right)$} & $\mathbf{N}$ & 23.92 & 94.76 & 141.83 & 12.62 & 41.28 & 4.63 & 74.17 \\
\hline & D & 24.25 & 97.53 & 144.23 & 13.19 & 42.15 & 4.36 & 65.59 \\
\hline \multicolumn{2}{|l|}{ Bulk sample } & 21.00 & 99.67 & 146.33 & 11.56 & 38.14 & 4.74 & 54.33 \\
\hline \multicolumn{2}{|l|}{ Sids 1 (P1) } & 19.98 & 96.00 & 144.33 & 11.78 & 37.32 & 4.55 & 54.00 \\
\hline \multicolumn{2}{|l|}{ Misr 2 (P2) } & 21.89 & 93.33 & 142.67 & 12.22 & 39.61 & 4.53 & 58.11 \\
\hline \multirow{2}{*}{ OG\% (Bulk) } & $\mathbf{N}$ & $13.92 * *$ & $-4.93 *$ & $-3.08 * *$ & 9.17 & $8.23 *$ & -2.32 & $36.52 * *$ \\
\hline & D & $15.48^{*}$ & $-2.15^{*}$ & $-1.44^{*}$ & $14.10 * *$ & $10.51 * *$ & $-8.02 * *$ & $20.73^{* *}$ \\
\hline \multirow{2}{*}{ OG\% (BP) } & $\mathbf{N}$ & $9.27 * *$ & 1.53 & -0.59 & 3.27 & 4.22 & 1.76 & $27.64 * *$ \\
\hline & D & 10.78 & $4.50 * *$ & 1.09 & 7.94 & 6.41 & -4.18 & $12.87 * *$ \\
\hline & & \multicolumn{7}{|c|}{ Evaluation under deficit irrigation } \\
\hline \multicolumn{2}{|c|}{$\mathrm{F}_{4}$ families $\left(\mathrm{C}_{1}\right)$} & 16.48 & 87.96 & 138.46 & 11.51 & 38.01 & 3.66 & 54.83 \\
\hline \multicolumn{2}{|c|}{ Bulk sample } & 14.26 & 91.67 & 141.67 & 11.27 & 32.58 & 3.89 & 42.33 \\
\hline \multicolumn{2}{|l|}{ Sids 1 (P1) } & 15.96 & 89.00 & 139.33 & 11.25 & 35.99 & 3.95 & 45.67 \\
\hline \multicolumn{2}{|l|}{ Misr 2 (P2) } & 15.83 & 86.33 & 136.33 & 10.73 & 38.79 & 3.84 & 44.00 \\
\hline \multicolumn{2}{|l|}{ OG\% (Bulk) } & $15.57 * *$ & -4.05 & -2.27 & 2.13 & $16.67 * *$ & -5.91 & $29.53 * *$ \\
\hline \multicolumn{2}{|l|}{ OG\% (BP) } & 3.26 & 1.89 & 1.56 & 2.31 & -2.14 & -7.34 & $20.06 * *$ \\
\hline \multirow{2}{*}{$F_{5}$ families $\left(C_{2}\right)$} & $\mathbf{N}$ & 20.78 & 91.40 & 138.23 & 11.81 & 39.27 & 4.50 & 61.64 \\
\hline & D & 21.35 & 91.70 & 139.73 & 12.39 & 40.31 & 4.29 & 55.75 \\
\hline \multicolumn{2}{|l|}{ Bulk sample } & 17.78 & 95.67 & 144.00 & 11.11 & 35.36 & 4.53 & 45.33 \\
\hline \multicolumn{2}{|l|}{ Sids 1 (P1) } & 18.00 & 94.67 & 142.67 & 10.89 & 37.06 & 4.48 & 48.00 \\
\hline \multicolumn{2}{|l|}{ Misr 2 (P2) } & 17.80 & 92.67 & 140.67 & 10.67 & 38.03 & 4.40 & 46.00 \\
\hline \multirow{2}{*}{ OG\% (Bulk) } & $\mathbf{N}$ & $16.87 * *$ & $-4.46^{* *}$ & $-4.01 * *$ & 6.30 & $11.06^{* *}$ & -0.66 & $35.98 * *$ \\
\hline & D & $20.08 * *$ & $-4.15^{* *}$ & $-2.97 *$ & $11.52 *$ & $14.00 * *$ & -5.30 & $22.99 * *$ \\
\hline \multirow{2}{*}{ OG\% (BP) } & $\mathbf{N}$ & $15.44 * *$ & -1.37 & -1.73 & 8.45 & 3.29 & 0.45 & $28.42 * *$ \\
\hline & D & $18.61 * *$ & -1.05 & -0.67 & $13.77 * *$ & 6.02 & -4.24 & $16.15^{*}$ \\
\hline
\end{tabular}

$\mathrm{N}=$ group selected under normal irrigation $\quad \mathrm{D}=$ group selected under deficit irrigation $\quad$ OG = observed gain *, **significant at 5 and $1 \%$ levels of probability, respectively.

pedigree selection for grain yield was effective in increasing grain yield. Also he found a decrease in 100-kernel weight from the bulk sample when selection was practiced at normal and drought stress.

3.3.Drought susceptibility index and sensitivity to environments

The drought susceptibility index (DSI) and sensitivity to environments of the selected families for grain yield plant ${ }^{-1}$ are presented in Table(7). The present results indicated that among the families which were selected under normal irrigation and evaluated under both regimes, six families (No. 7, 23, 47, 67, 74 and 91) showed DSI of $0.61,0.96,0.37,0.94,0.58$ and 0.40 , respectively. The six families which gave DSI less than one gave less than one (less sensitivity) in the sensitivity test. These families 
Table (7): Drought susceptibility index (DSI) and sensitivity (S) to environments of selected families under normal irrigation and deficit irrigation after two cycles of selection for grain yield plant ${ }^{-1}$.

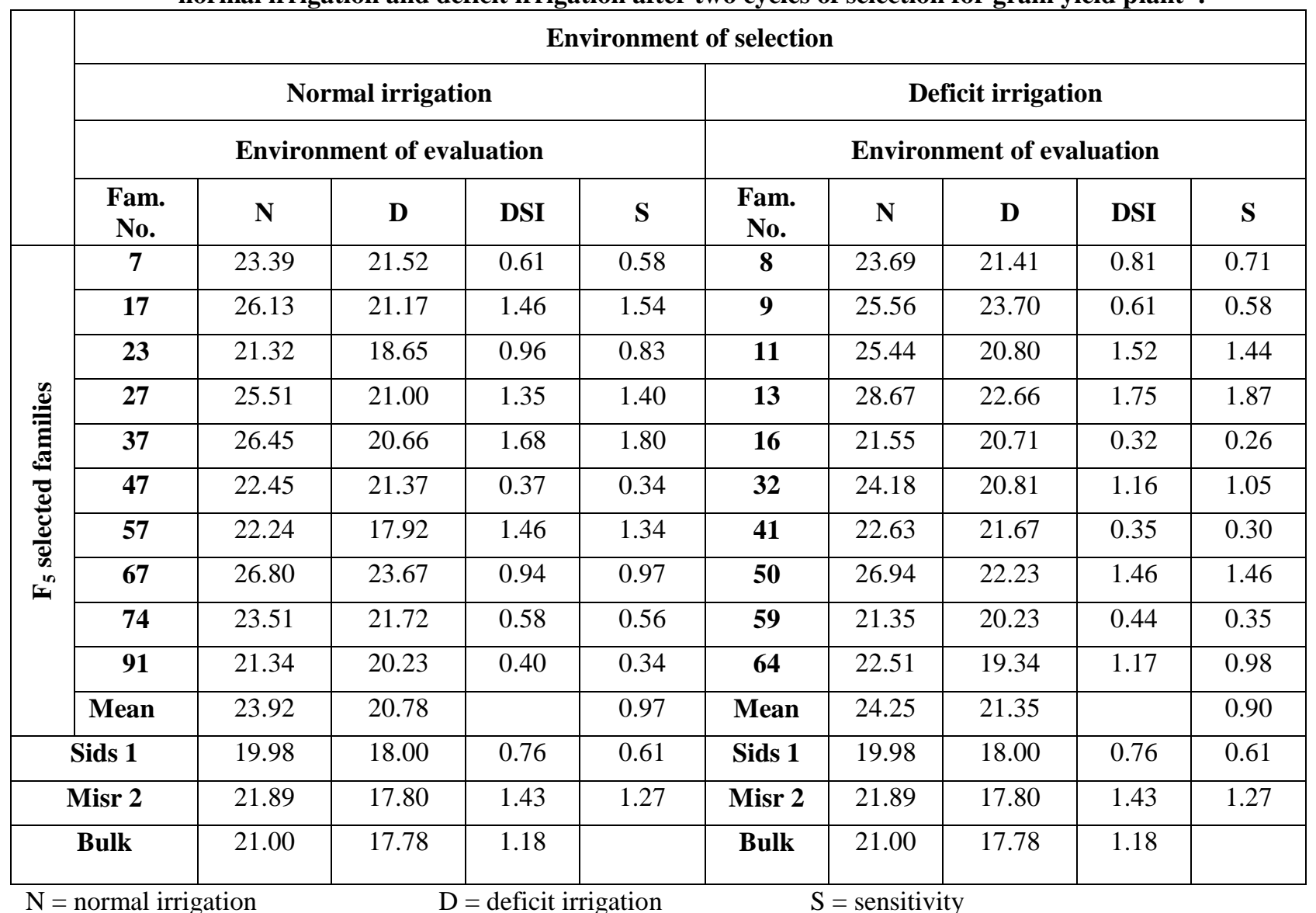

could be used as a source of drought tolerance or factors contributing to general adaptation. It could be noticed that the superior family No. 67 was less susceptible and less sensitive to drought and showed significant observed gain over the better parent under normal and deficit irrigation, so it can be a good and stable cultivar. The results of deficit irrigation group of families showed that five families (No. 8, 9, 16, 41 and 59) gave DSI of $0.81,0.61,0.32,0.35$ and 0.44 , respectively, and all these families gave lower values of sensitivity. The families No. 11, 13 and 50 had high grain yield plant ${ }^{-1}$ under normal and deficit irrigation, but they had DSI more than unity. On the other hand, the family No. 9 was less susceptible and less sensitive to drought, and showed significant observed gain over the better parent under normal and deficit irrigation, so it can be a good and stable cultivar.

The mean sensitivity to drought of the selected families for high grain yield plant ${ }^{-1}$ under normal irrigation was 0.97 , while it was 0.90 for the selected families under deficit irrigation (Table 7). These results concluded that the antagonistic selection reduced sensitivity to drought stress and synergistic selection increased it. The relative merit after two cycles of selection for high grain yield was 1.11 when selection was under normal and deficit irrigation and evaluated under normal irrigation, while it was 1.19 when selection was under normal and deficit irrigation and evaluated under deficit irrigation. These results indicated that antagonistic selection was better than synergistic selection to increase grain yield plant ${ }^{-1}$ in these materials, either evaluation was under normal or deficit irrigation. Similar results have been reported by Jinks and Connolly (1973 and 1975), Jinks and Pooni (1982), Ceccarelli and Grando (1991 a and b), Mohamed (2001) and Kheiralla et al. (2006). Mahdy (2012) found that antagonistic selection reduced sensitivity of the selected families, while antagonistic selection decreased it. Falconer (1990) reported that to increase the mean performance, selection should be made upwards in a bad environment, and conversely, to decrease mean performance downwards selection should be made in a good environment. 


\section{REFERENCES}

Abd El-Kader M.N.T. (2011). Selection for yield and some quality traits in durum wheat (Triticum turgidum var. durum). Ph.D. Thesis, Agron. Dept., Fac. Agric., Assiut Univ., Egypt.

Abd-El-Haleem S.H.M., Ehab, Metwali M.R. and Mohamed S.M.S. (2012). Efficiency of pedigree selection in bread wheat under drought stress conditions. Life Sci. J. 9 (4): 3423-3429.

Ahmed A.A.S., El-Morshidy M.A., Kheiralla K.M., Uptmoor R., Ali M.A. and Mohamed N.E.M. (2014). Selection for drought tolerance in wheat population (Triticum aestivum L.) by Independent culling levels. World J. Agric. Res., 2 (2): 56-62.

Ahmed T.A. (2006). Efficiency of late and early selection for grain yield under different selection criteria and DNA marker polymorphism in wheat (Triticum aestivum L.). Assiut J. of Agric. Sci., 37 (2): 1-16.

Ali M.A. (2011). Pedigree selection for grain yield in spring wheat (Triticum aestivum L.) under drought stress conditions. Asian J. Crop Sci., 3 (4): 158-168.

Amin I.A. (2003). Selection for drought tolerance in wheat. Ph.D. Thesis, Agron. Dep. Fac. Agric., Minia Univ., Egypt.

Amin-Alim M. (2011). The effects of water and heat stress on wheat. Agric. Trop. Et Subtropical, 44 (1): 44-47.

Attia I.A. (2003). Selection for drought tolerance in wheat. Ph. D. Thesis, El-Minia University, Egypt.

Betran F.J., Beck D., Banziger M. and Edmeades G.O. (2003). Genetic analysis of inbred and hybrid grain yield under stress and non stress environments in tropical maize. Crop Sci. J. 43 (3): 807-817.

Burton G.W. (1952). Quantitative inheritance in grasses. $6^{\text {th }}$ Int. Grassland Cong. Proc., 1: 227-283, Pennsylvania state.

Byrne P.F., Bolanos J., Edmeades G.O. and Eaton D.L. (1995). Gains from selection under drought versus multiplication testing in related tropical maize populations. Crop Sci. J. ,35 (1): 63-69.

Ceccarelli S. and Grando S. (1991a). Selection environment and environmental sensitivity in barley. Euphytica, 57 (2): 157-167.

Ceccarelli S. and Grando S. (1991b). Environment of selection and type of germplasm in barley breeding for lowyielding conditions. Euphytica 57 (3): 207-219.

Cheema N.M., Mian M.A., Ihsan M., Rabbani G. and Mahmood A. (2006). Studies on variability and some genetic parameters in spring wheat. Pak. J. Agri. Sci. 43 (1-2): 32-35.

Economic Affairs Sector, Ministry of Agricultural and Land Reclamation, Egypt. Annual report (2015).

El-Morshidy M.A., Kheiralla K.A., Ali M.A. and Said A.A. (2010). Response to selection for earliness and grain yield in wheat (Triticum aestivum L.) under normal and water stress conditions. Assiut J. of Agric. Sci., 41: 1-23.

El-Rawi K. and Khalafala A.M. (1980). Design and Analysis of Agricultural Experiments. El-Mousel Univ. Iraq.

Falconer D.S. (1989). Introduction to Quantitative Genetics. $3^{r d}$ ed. Longman, Hong Kong, pp 438.

Falconer D.S. (1990). Selection in different environment: effects on environmental sensitivity (reaction norm) and mean performance. Genet. Res. 56 (1): 57-70.

Fischer R.A. and Maurer R. (1978). Drought resistance in spring wheat cultivars. I. Grain yield response. Crop and Pasture Sci., 29 (5): 897-912.

Ismail A.A. (1995). Pedigree selection for grain yield, grain weight and earliness in two segregating populations of spring wheat. Assiut J. Agric. Sci., 24: 59-72.

Jinks J.L. and Pooni H.S. (1982). Determination of the environmental sensitivity of selection lines of Nicotiana rustica by selection environment. Heredity, 49 (3): 291-294.

Jinks J.L. and Connolly V. (1973). Selection for specific and general response to environmental differences. Heredity, 30: 33-40.

Jinks J.L. and Connolly V. (1975). Determination of environmental sensitivity of selection lines by the selection environment. Heredity, 34 (3): 401-406.

Kashif M. and Khaliq I. (2004). Heritability, correlation and path coefficient analysis for some metric traits in wheat. Int. J. Agri. Bio. 6 (1): 138-142.

Kheiralla K.A., El-Morshidy M.A. and Zakaria M.M. (2001). Inheritance of earliness and 
yield in bread wheat under favourable and late sowing dates. The second $\mathrm{Pl}$. Breed. Conf. October 2, 2001. Assiut University, 219-239.

Kheiralla K.A., El-Morshidy M.A., Tammam A.M. and Zakaria M.M. (2006). The efficiency of selection and environmental sensitivity for grain yield in wheat. Symposium: Status and Improvement Horizons of Field Crops in the Arab World. 30-31 October, 2006, Alepo Univ., Syria.

Kheiralla K.A., El-Morshidy M.A., Motawea M.H. and Saedid A. A. (2004). Performance and stability of some wheat genotypes under normal and water stress conditions. Assiut J. of Agric. Sci. 35 (2):73-94.

Mahdy E.E., El-Karamity A.E., Mokadem S.A. and Fouad H.M. (2012). Selection for grain yield and its components in two segregating populations. Minia Int. Conf. Agric. Irrig. In the Nile Basin Coun., 26 ${ }^{\text {th }}$ $29^{\text {th }}$ March 2012, p. 595-604.

Mahdy Rasha, E. (2007). Inheritance of yield, yield components and drought tolerance traits in bread wheat (Triticum aestivum L.). M.Sc. Thesis, Fac. Agric. Assiut Univ. Egypt.

Mahdy Rasha, E. (2012). Response to selection for earliness and yield in bread wheat under normal and drought conditions. Ph.D. Thesis, Fac. Agric. Assiut Univ. Egypt.

Mohamed A. A. (2001). Breeding for earliness and yield components in some Egyptian cotton crosses. PhD. Thesis Fac. Agric. Assiut Univ. Assiut, Egypt.

Nazari L. and Pakniyat H. (2010). Assessment of drought tolerance in barley genotypes. J. Appl. Sci. 10 (2): 151-156.

Omara M.K., El-Defrawy M.M., Tammam A.M. and Kassam A.A.F. (2004). Genetic control of pre-anthesis attributes of wheat plant and their associations with yield under heat stress. Assiut J. of Agric. Sci. 35 (4): 97-115.

Passioura J. (2007). The drought environment: physical, biological and agricultural perspectives. J. Exp. Bot. 58 (2): 113-117.

Rathjen A.J. (1994). The biological basis of genotype environment interaction. Its definition and management. In Proceedings of the Seventh Assembly of the Wheat Breeding Society of Australia, Adelaide, Australia.

Snedecor G.W. and Cochran W.G. (1980). Statistical methods. $7^{\text {th }}$ ed. Iowa State Unv. Press., Ames., Iowa, U.S.A.

Soliman G.M.M., El-Morshidy M.A., Kheiralla K.A. and Amin I.A. (2015). Selection efficiency under both normal irrigation and water deficit conditions in durum wheat. Egypt. J. Agric. Res., 93 (2): 335351.

Tammam A.M., El-Ashmoony M.S.F., ElSherbeny A.A. and Amin I.A. (2004). Selection responses for drought tolerance in two bread wheat crosses. Egypt J. Agric. Res. 82 (3): 1213-1226.

Walker T.T. (1960). The use of a selection index technique in the analysis of progeny row data. Emp. Cott. Rev. 37: 81-107.

Zakaria M.M. (2004). Selection for earliness and grain yield in bread wheat (Triticum aestivum $\mathrm{L}$.) under different environmental conditions. Ph.D. Thesis, Fac. of Agric., Assiut Univ., Egypt .

Zakaria M.M., El-Morshidy M.A., Khieralla K.A. and Tammam A.M. (2008). Direct selection for grain yield and correlated response in bread wheat under normal and late sowing dates. Assiut J. of Agric. Sci. 39:1-16.

Zarei L., Farshardfar E., Haghparast R., Rajabi R. and Badieh M.M.S. (2007). Evaluation of some indirect traits and indices to identify drought tolerance in bread wheat (Triticum aestivum L.). Asian J. Plant Sci. 6 (8): 1204-1210. 
الإنتخاب لمحصول الحبوب تحت نظامي الري العادي والري المنذفض في قمح الخبز

$$
\text { أيمن جمال عبدالراضى }
$$

قسم بحوث القمح - معهد بحوث المحاصيل الحقلية - مركز البحوث الزر اعية ـالجيزة ـ مصر

\begin{abstract}
ملخص

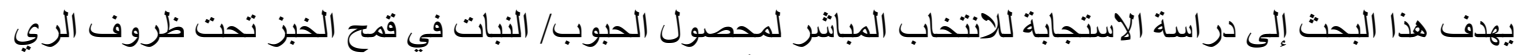

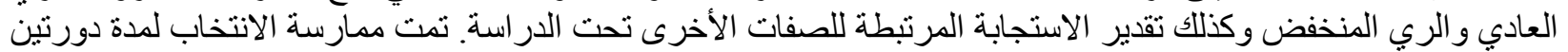

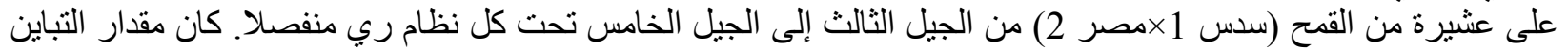

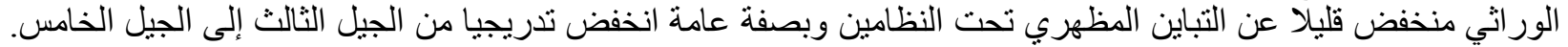

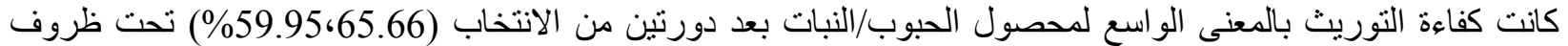

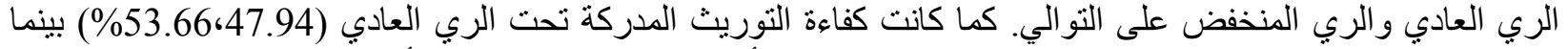

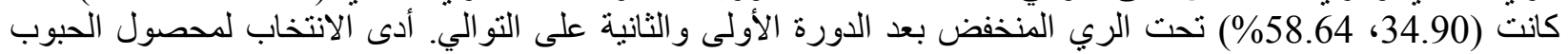

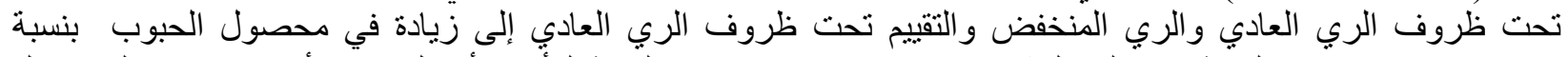

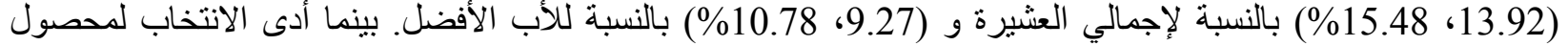

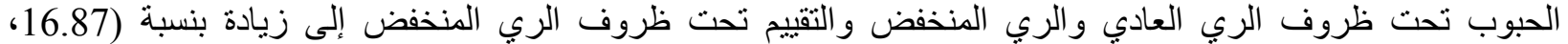

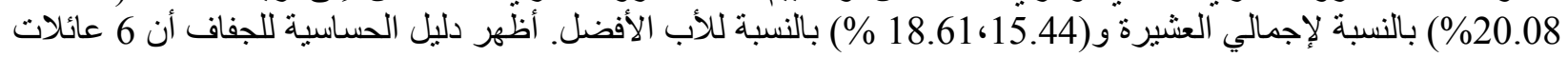

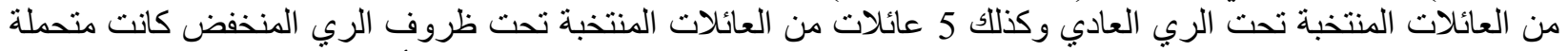

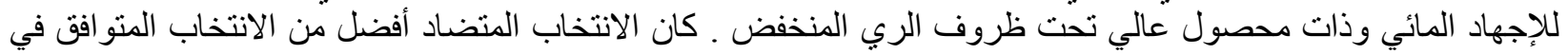

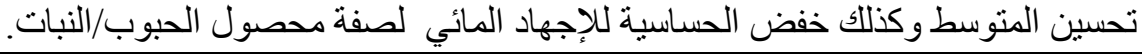

المجلة العلمية لكلية الزراعة ـ جامعة القاهرة ـ المجلا (67) العدد الرابع (أكتوبر 2016 ) : 295-306.
\end{abstract}

